\title{
Chapter 7 \\ Limitations to production and choice of species in finishing pastures
}

\author{
A.J. Harris and A.C.P. Chu \\ Grasslands Division, DSIR, Gore \\ Massey University, Palmerston North
}

\section{INTRODUCTION}

During the past 15 years many new pasture species and cultivars have been released and are now commercially available. However, with the exception of Nui and Ellett ryegrasses, only a few have received enthusiastic acceptance by farmers. Acceptance depends in part to the extent to which the new plant can overcome periods of low productivity. Other reasons which are the frequent subject of comment by seed merchants include historic use of a pasture mixture and seed cost.

In the summer-moist regions of New Zealand, perennial ryegrass and white clover are traditionally used. During favourable seasons, production from these pastures is adequate for finishing stock. However, periodic summer droughts and low winter temperatures can create problems for farmers, particularly under high stocking rates.

Temperature and water are the two most important environmental factors determining total and seasonal pasture productivity and influencing the use of pasture plants. Changes in these factors are the major cause of annual variation in production between seasons and years. They can influence plant performance as components of weather or by association with soil physical characteristics. We will describe limitations imposed by temperature and moisture on pasture plants in the finishing country of Southland and Manawatu and, where appropriate, comment on choice of species. There are obviously other areas in New Zealand where the effects described also operate.

Southland has a livestock industry based almost exclusively on sheep for lamb meat and wool. The major pasture restriction is in winter and early spring when growth rates do not meet animal requirements. The farming pattern of the Manawatu is more complex, with enterprises based on sheep, beef and dairying either solely or in combinations. The area is influenced less than Southland by winter growth restrictions but unlike Southland does have some restrictions from summer moisture stress.

\section{TEMPERATURE EFFECTS}

Latitude has a pronounced effect on temperature and hence on potential pasture production. In the absence of moisture stress, limitations to pasture growth due to high temperature rarely occur in New Zealand. On the other hand, low temperature does limit potential production. A mean monthly temperature below $10^{\circ} \mathrm{C}$ occurs for 6 months at Gore whereas it is only for 3 months at Palmerston North. Taking production at Palmerston North as 100, the corresponding production figures for Gore during spring, summer, autumn and winter are 78, 87, 64 and 36 respectively. Under these conditions, using more cool-temperature-active species and cultivars can improve pasture productivity.

\section{Perennial ryegrass}

In Southland, use of the technique described as all grass wintering has meant that the autumn productivity of the grass component is important to enable sufficient feed reserves to build up. The widespread adoption of this technique from a foragecrop-based wintering system to one using grass is reflected in the change of use of perennial ryegrass cultivars shown in Table 7.1. The data are from the records of one of the major firms supplying seed to farmers. The almost complete substitution of Nui and Ellett for Ruanui is evident. There is also a downward trend in the use of Manawa ryegrass which may be due to an observed decrease in its persistency, or a lesser need when Nui rather than Ruanui is used. Table 7.2 provides information on seasonal distribution of 3 perennial ryegrass cultivars under sheep grazing in Southland. Under these conditions, Nui- outyielded Ariki- and Ruanui-based pastures although the marked advantage in ryegrass production in the Nui sward was offset to some 
extent by high yields of white clover in Ariki (30\%) and Ruanui (36\%) compared with Nui $(25 \%)$. An important feature of this change is the gain in total herbage from Nui ryegrass in autumn. The winter production of both Nui and Ariki is higher than that of Ruanui. This fits the requirement of all grass wintering systems.

Table 7.1 Percentage retail sales of herbage seeds in eastern Southland/West Otago.

\begin{tabular}{|c|c|c|c|c|}
\hline & \multicolumn{2}{|c|}{$\begin{array}{c}1978-79 \\
\% \text { of all \% of }\end{array}$} & \multicolumn{2}{|c|}{$\begin{array}{c}1983-84 \\
\% \text { of all \% of } \\
\text { Seed Group }\end{array}$} \\
\hline Ruanui & 50.3 & 83.1 & 13.0 & 21.5 \\
\hline Nui & 4.3 & 7.1 & 44.4 & 73.7 \\
\hline Ellett & - & - & 2.5 & 4.1 \\
\hline Vigor & - & - & $=$ & - \\
\hline Ariki & 5.9 & 9.8 & 0.4 & 0.7 \\
\hline $\begin{array}{l}\text { All perennial } \\
\text { ryegrasses }\end{array}$ & 60.5 & & 60.3 & \\
\hline Manawa & 10.7 & 58.9 & 5.4 & 43.8 \\
\hline Paroa & 3.7 & 20.1 & 2.9 & 23.3 \\
\hline Moata & - & $=$ & 1.5 & 11.9 \\
\hline Tama & 3.8 & 21.0 & 2.6 & 21.0 \\
\hline $\begin{array}{l}\text { All short term } \\
\text { ryegrasses }\end{array}$ & 18.2 & & 12.4 & \\
\hline Apanui & 7.1 & 56.9 & 5.9 & 37.4 \\
\hline Kahu & 5.4 & 43.1 & 9.8 & 62.6 \\
\hline Wana & - & $\rightarrow$ & - & - \\
\hline Matua & - & 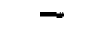 & - & - \\
\hline All other grasses & 12.5 & & 15.7 & \\
\hline Huia & 6.0 & 67.6 & 9.2 & 79.0 \\
\hline Pitau & - & - & - & - \\
\hline Hamua & 0.7 & 8.5 & 0.9 & 7.7 \\
\hline Turoa & 2.1 & 23.9 & 1.2 & 10.1 \\
\hline Pawera & - & - & 0.4 & 3.2 \\
\hline All red clovers & 2.8 & 32.4 & 2.5 & 21.0 \\
\hline All clovers & 8.8 & & 11.7 & \\
\hline
\end{tabular}

Source: K.J. Smith, Wrightson NMA Ltd., Gore.

Table 7.2 Seasonal yields of three ryegrass/Huia white clover pastures at Gore (DM kg/ha). (Mean of 3 years).

\begin{tabular}{lrrrrr}
\hline \multicolumn{5}{c}{ Spring } & Summer \\
\hline Sown grass & & & & & \\
$\quad$ Nui & 3900 & 3490 & 2215 & 795 & 10410 \\
Ruanui & 3300 & 2590 & 1520 & 540 & 7950 \\
Ariki & 3660 & 3310 & 1565 & 715 & 9260 \\
$\quad$ d.05 & 250 & 330 & 130 & 60 & 520 \\
Total Herbage & & & & & \\
$\quad$ Nui & 5550 & 5830 & 2835 & 956 & 15180 \\
Ruanui & 5800 & 5750 & 2410 & 812 & 14780 \\
Ariki & 5570 & 5730 & 2370 & 931 & 14580 \\
$\quad$ d.05 & NS & NS & 170 & 90 & 480 \\
\hline
\end{tabular}

Source: Lancashire et al. 1979. Proceedings of the New Zealand Grassland Association 40,114- 124.

\section{White clover}

The effect of temperature is most marked on the performance of white clover. The optimum for growth of this species is $20-24^{\circ} \mathrm{C}$ which indicates that for much of the year in Palmerston North and particularly Gore, conditions are not ideal. Until alternatives have been fully tested or a cultivar betteradapted than Huia to southern New Zealand is developed, then in Southland white clover will best be represented by Huia. Yield advantages of Pitau over Huia are greatest in Northland and decline further south. On average, main growing season temperature decreases by approximately $10 \%$ between Northland and Southland which is a shift from a temperature regime more advantageous to Pitau in the north to one favouring Huia in the south. In winter, average temperature shows a greater decline (approximately 16\%). The southern regions are cool enough to severely restrict the growth of both cultivars whereas the northern regions are warm enough to allow Pitau to express its greater cool season growth potential. Experiments in controlled-environment growth cabinets showed that a day temperature of $25^{\circ} \mathrm{C}$ and a night temperature of $20^{\circ} \mathrm{C}$ favours Pitau which outyielded Huia, but at a regime of $20^{\circ} \mathrm{C}$ day and $15^{\circ} \mathrm{C}$ night the reverse was the case.

An experiment in the late 1960's described the comparative performance of Pitau and Huia at 3 locations in New Zealand. At Gore, there was a consistent inferiority of pasture containing Pitau as only in the clover constituent during the cold period of the second year of measurement was Pitau superior.

Although there is evidence in the south of good performance from the clover component of Pitaubased swards, total herbage yield is similar or poorer than pastures using Huia. Huia is a denser plant than Pitau and spreads through the sward more easily. Poor or slow establishment are reasons for the lack of use of Pitau in the southern environment and at this stage it appears doubtful that Pitau will be able to make a significant contribution to the agriculture there.

\section{Greenfeeds}

When pasture sowing is delayed to the extent that low temperatures are likely to prejudice establishment, temporary pastures are recommended. The annual ryegrass, Tama, and the Italian ryegrasses, Paroa and Moata, as well as cereal greenfeeds, are all useful. Early evidence showed an advantage from early autumn sowing of both Tama and $\mathrm{CRD}$ ryecorn in total production and seasonal 
spread. If sowing was completed in early March, greenfeed was available as flushing feed for ewes while recovery growth was able to provide high quality material for the latter weeks of pregnancy in late winter-early spring. Under these circumstances the faster growth of Tama following its first defoliation was an advantage. It was concluded that should circumstances force late sowing, better production up to mid August would be expected from ryecorn, but following this, in later spring, Tama would give better results.

Combinations of Tama and Rahu ryecorn compared seeding rates from 0 to $30 \mathrm{~kg} / \mathrm{ha}$ of Tama and from 0 to $140 \mathrm{~kg} / \mathrm{ha}$ of Rahu. Most of the production over the critical pre-lambing and postlambing period was provided by Tama. Importantly, this component of the mixture was suppressed in August-September only at the low sowing rate of 10 $\mathrm{kg} / \mathrm{ha}$ of Tama. It seems that advantage can be taken of the early winter growth of Rahu without sacrificing early spring production from Tama. Consideration of total yield and its distribution indicated an optimum sowing rate combination under moist, high fertility conditions of $30 \mathrm{~kg} / \mathrm{ha}$ of Tama with $70 \mathrm{~kg} / \mathrm{ha}$ of Rahu. Although ryecorn recovers from grazing better than other cereals, its high growing point and early flowering make it vulnerable to hard grazing especially in late winter. These features combine to remove Rahu from the swards at this time and allow expression of the spring potential of Tama.

More recent evidence suggests that biennials such as Moata and Paroa will provide greater management flexibility in the timing of permanent sward renewal.

\section{WATER EFFECTS}

\section{Summer dry}

While both Manawatu and Southland enjoy a similar and relatively even rainfall distribution and can be considered as 'summer moist', evaporation rate in Manawatu can be higher than mean rainfall for eight months of the year (October to May). Consequently, pasture production is frequently limited by soil moisture stress. The difference in production between irrigated and non-irrigated pastures in the Manawatu has been estimated to be over $35 \%$. The limitation due to moisture stress as a result of soil type differences is illustrated by the coastal sand country of the Manawatu which has a similar pasture growth pattern to those of the pumice soils at Wairakei and the dryland soils at Winchmore, although the rainfall patterns of these districts are different.
Moisture stress will affect pasture production in at least three ways. First, the most obvious effect is the reduction in total herbage production, especially yield of fresh material. Where moisture stress develops slowly (as occurs in the field) there is reduction in leaf extension growth even under relatively mild stress before signs of visible wilting. This will result in a reduction in the accumulation of fresh herbage, but not, during the initial stages, the dry matter yield because of an increase in percentage dry matter $(\% \mathrm{DM})$. Perennial ryegrass leaves which were from well-watered plants had $12 \%$ DM compared with $17 \%$ from mildly stressed plants.

Second, when drought is severe, the aboveground herbage will be killed and the accumulating dead material will reduce the overall nutritive quality of the herbage. But at mild or even moderate levels of drought in both temperate and tropical grasses'and legumes, in vitro dry matter digestibility, nitrogen content and soluble sugars are frequently higher in the stressed than the non-stressed plant material. Under field conditions in New Zealand, leaf rusts (Puccinia spp.) tend to become a serious problem during the drier months, especially on perennial ryegrass, thereby reducing the overall herbage quality.

Third, with prolonged drought, dry matter production will cease and persistence of pasture plants may be affected, resulting in much poorer winter and subsequent spring production.

Species Choice. It is essential to have species and cultivars able to respond quickly in autumn before the onset of colder and less favourable growing conditions. Thus, even in the summer moist regions of New Zealand, the use of summer active and drought resistant species such as lucerne, Wana cocksfoot, Nui and Ellett ryegrass, Pawera red clover, Roa tall fescue and Matua prairie grass should be more widely recommended. Wana, Roa and Matua have other advantages for the dry summer months, in that they are more rust resistant and Matua can maintain its quality and palatability even when reproductive. Within the ryegrasses, Nui and Ellett persist better than Ruanui during drought and recover faster after the drought.

Irrigation. Although irrigation is the obvious choice to overcome herbage production problems associated with drought, availability of water and its cost relative to financial gain must be carefully considered. In summer-dry regions such as lowland Canterbury, irrigation of finishing pastures is essential and financially beneficial. However in summer-moist regions such as the Manawatu, there is little information available on the benefits of irrigation relative to cost. Reducing the number of 
irrigations per season is one way to reduce cost. At Winchmore, it has been shown to be more economical to irrigate less frequently (2-3 times vs. 8 times per season) and accept a $10 \%$ lower herbage yield. With irrigation, the year to year variation in herbage production is reduced to $\pm 12 \%$ from $\pm 48 \%$ under no irrigation. Even at a reduced number of irrigations per season, a more predictable herbage production pattern is ensured, thus making management decisions more flexible.

Very little information is available on the benefits of irrigation and ways of improving its efficiency in the summer moist regions of New Zealand. For example, one has to question whether ryegrass/white clover pasture is necessarily the best pasture to irrigate. For both yield and quality it may be more profitable to irrigate a sward of Matua prairie grass and Pawera red clover over the summer months. The other question is whether it is economical to add nitrogen to the irrigated paddocks to capitalise on the favourable growing conditions. With continued increase in the cost of irrigation, farmers will be very interested in these answers.

Winter wet

The other problem relating to water as a factor limiting pasture production is excessive moisture, especially during winter. Pasture utilisation is hampered under waterlogged conditions. Although treading damage to pasture plants can be severe, the worst damage is that to the soil structure which takes much longer to recover. Good drainage is therefore essential to allow for efficient winter grazing, although excessive drainage can accentuate the summer drought problems discussed previously. Drainage for the summer moist regions should be designed as a system of water control including drainage, harvesting and conservation. Annual rainfall for most of the summer moist areas should be adequate for pasture growth if we can redistribute some of the winter moisture into summer. If this can be done the need for drought resistant special purpose type of pasture in the summer moist region will be less, and species selection will be much simpler.

In Southland, the effect of a high number of rain days is particularly marked on farms where cereal cropping is mixed with livestock enterprises. Because time of sowing is important for the growth and development of white clover in permanent pasture, if circumstances of high rain days preclude the harvest of cereal crops or make the effective tillage of these soils for the permanent sward difficult, thought should be given to the establishment of a temporary sward to allow sowing when conditions favour clover establishment.

\section{CONCLUSION}

The most important pastoral association in New Zealand is perennial ryegrass and white clover. It has the ability not only to tolerate a wide range of climatic conditions but to withstand management abuse.

In the summer-moist regions of New Zealand, low winter temperatures are not extreme and serious moisture stress in summer seldom occurs for more than 6 weeks. During these summer dry periods, drought resistant species perform better than ryegrass. However, for the rest of the year, the persistency and productivity of well-managed perennial ryegrass/white clover are frequently superior to other species. Under conditions where other species have an advantage of higher performance together with ease of management their use should be more widely recommended.

\section{SWMMART}

1. Perennial tyegrass/ white clover pastures are still best for finishing stock in summer-moist areas such as Southland and Manawatu;

2. Nui and Ellet perennial ryegrasses suit the technique of all-grass-wintering in cool temperate Southland.

3. Huia is the best cultivar for the southern region but in the north Pitau is recommended.

4. Where permanent pasture soming is delayed in autumn, temporary swards from Moata. Tama, Paroa or the cereal, ryecorn is advocated.

5. Summer moisture stress can limit production from perennial ryegrass/ white clover in the Manawatu. Species such as Wana cocksfoot, Roa tall fescue, Matua praire grass. Pawera red clover and lucente have a place there.

6. Drainage, harvesting and conservation of water will alleviate problems of excess water in winter and shortage in summer and reduce the need for spectal purpose pastures in sumner moist finishing country 


\section{FURTHER READING}

Brougham R.W. 1966. Potential of present type pastures for livestock feeding. New Zealand Journal of agricultural Science I, 19-22.

Brown K.R. 1973. Effects of four times of sowing on 'Grasslands Huia' and 'Grasslands 4700' white clovers. New Zealand Journal of experimental Agriculture I, 165-70.

Chu A.C.P. 1979. (Unpublished). Aspects of water deficit and vegetative growth in selected pasture and forage grasses. Ph.D thesis. Massey University.

Harris A.J., Johnston J.M. 1969. Production of 'Grasslands Tama' and ryecorn compared. New Zealand Journal of Agriculture 119, 45-8.

Hay R.J.M., Ryan D.L 1978. Effect of seeding rate on yield distribution of Tama/Rahu greenfeed at two sites in Southland. Proceedings of the New Zealand Grassland Association 39, 165-73.

Hoglund J.H., Brock J.L. 1974. Growth of 'Grasslands Huia' and 'Grasslands 4700' white clovers. New Zealand Journal of Agricultural Research 17, 4 1-53.

Lambert J.P.; Vartha E.W., Harris A.J. 1970. Progress report on 'Grasslands 4700' white clover. Proceedings of the New Zealand G rassland Association 31, 135-42.

Lancashire J.A., Latch G.C.M. 1966. Some effects of crown rust (Puccinia coronata Corda) on the growth of two ryegrass varieties in New Zealand. New Zealand Journal of agricultural Research 9, 628-40.

Lancashire J.A. 1983. Potential and performance of some new herbage cultivars in New Zealand grassland farming. New Zealand Seeds Promotion Council First Annual Industry Conference, Ashburton.

Lancashire J.A. 1984. The physical boundaries of temperate pasture species in New Zealand. New Zealand Agricultural Science $18,98-110$.

Lancashire J.A., Harris A.J., Armstrong C.S., Ryan D.L. 1979. Perennial ryegrass cultivars. Proceedings of the New Zealand Grassland Association 40, 114-24.

Mitchell K.J. 1956. Growth of pasture species under controlled environment. New Zealand Journal of Science and Technoiogy $A \hat{3} 8,2013-16$.

Mitchell K.J. 1963. Production potential of New Zealand pasture land. Proceedings of the Institute of Agricultural Science 9, $80-96$.

Radcliffe J. 1979. Variations in grassland production. p. 79-97. In: Symposium on the value of meteorology in economic planning. New Zealand Meteorological Service, Wellington.

Rumba11 P.J. 1977. Pasture plant, water-table interactions on Manawatu sandy country. Proceedings of the New Zealand Grassland Association 39, 53-60.

Stoker R. 1979. A little water can do more good. New Zealand Farmer September. 39-41.

Vartha E.W., Rae S.J. 1973. The growth of 'Grasslands Tama' Westerwolds ryegrass alone and in mixture with cereals. Proceedings of New Zealand Grassland Association 34(2), 169-76. 